\title{
CULPA E MÁ CONSCIÊNCIA EM NIETZSCHE E FREUD
}

\section{Guilt and bad conscience in Nietzsche and Freud}

Eduardo Sugizaki ${ }^{1}$

\section{Resumo}

Parte-se das interrogações de Nietzsche e de Freud sobre a agressividade do animal homem. Pela via da epistemologia francesa, procura-se colocar essas interrogações no solo comum do nascimento das ciências da vida. Procura-se levantar as conseqüências que o Estado, na obra de Nietzsche, e a civilização (Kultur), na obra de Freud, trouxeram em termos de alteração da agressividade humana. Apesar da diversidade de caminhos, as obras dos dois autores tangenciam-se na idéia de que a agressividade que não pode ser manifestada livremente, pela pressão do Estado ou da civilização, retorna para dentro do indivíduo e contra ele próprio, produzindo o que Freud chama de culpa e o que Nietzsche chama de má consciência moral. A via de Freud, diferentemente da de Nietzsche, atravessa a idéia de instância da mente. Em ambos os autores, uma referência ao estágio primitivo da evolução humana é determinante.

Palavras-chave: Consciência moral; Agressividade humana; Sentimento de culpa.

1 Mestre em Filosofia pela UFGO. Professor Adjunto na Universidade Católica de Goiás - UCG.

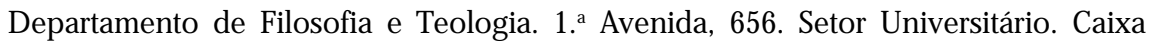
Postal 86. CEP 74605-020, Goiânia - Goiás. Fone: (62) 227-1142.

E-mail: sugizaki@brturbo.com

Revista de Filosofia, Curitiba, v. 17 n.20, p. 67-84, jan./jun. 2005. 


\section{Abstract}

One starts from Nietzsche's and Freud's interrogations concerning the aggressiveness of the human animal. By the employment of French epistemology, one attempts to place these interrogations on a common ground as linked to the birth of the sciences of life. What is sought is to constitute the consequences that the State, in Nietzsche's work, and civilization (Kultur), in Freud's work, brought forth in terms of the alteration of human aggressiveness. In spite of the diversity of approaches, the works of the two authors agree on the idea that aggressiveness which cannot be manifested freely is introverted in the individual and even against him through the pressure of the State or civilization, thus producing what Freud calls guilt and what Nietzsche calls bad moral conscience. Freud's approach, which is different from Nietzsche's, passes through the idea of the 'instantia' of the mind. On both authors, a reference to a primitive stage of human evolution is determinant. Keywords: Moral conscience; Human aggressiveness; Sense of guilt.

“Criar um animal que pode 'fazer promessas' - não é esta a tarefa paradoxal que a natureza se impôs, com relação ao homem?' (NIETZSCHE, 1998, p. 47).

"Que acontece [no desenvolvimento do indivíduo humano civilizado] para tornar inofensivo seu desejo de agressão?” (FREUD, 1997, p. 83).

Questões que dizem respeito a transformações qualitativas em processos naturais, a produção da memória no homem, a passagem de um estado de agressividade selvagem para um estado de convivência pacífica e civilizada, no lugar da crença em uma alma transcendental, onticamente imutável, imortal, que eleva o homem acima e além do mundo sensível. "Quando se fala de humanidade, diz Nietzsche (1996, p. 73), a noção fundamental é a de algo que separa e distingue o homem da natureza. Mas tal separação não existe... O ser humano... é totalmente natureza". Quanto a Freud, em sua resposta à carta aberta de Einstein a propósito da guerra, não hesita em dizer que é por "um princípio geral que os conflitos de interesses entre os homens são resolvidos pelo uso da violência. É isto que se passa em todo o reino animal, do qual o homem não tem motivo por que se excluir" (FREUD, 1974b, p. 246).

Revista de Filosofia, Curitiba, v. 17 n.20, p. 67-84, jan./jun. 2005. 
Atentos à história dos saberes ocidentais, sabemos que este horizonte de consideração é datado. O mecanicismo cartesiano instaurara a ciência clássica ao determinar, com os limites do mundo sensível, a res extensa, as fronteiras suficientes do saber humano. Deus criou 0 mundo, mas importa à ciência que as leis impostas ao funcionamento da natureza não podem ser modificadas, nem por ele, nem pelo astucioso e enganador gênio do mal (JACOB, 1983, p. 36). Sem isso, não há ciência clássica porque é determinante que a natureza se deixe governar por leis permanentes, decifráveis e harmonizáveis (JACOB, 1983, p. 37). Duas coisas, entretanto, ficam fora da mecânica do mundo e, portanto, além do alcance da ciência. Deus, que "tendo criado o mundo e tendo-lhe comunicado o movimento inicial, não intervém mais"; o pensamento humano, a res cogitans, cuja complexidade ultrapassa metafisicamente 0 que é extenso e sujeito à mecânica (JACOB, 1983, p. 42).

Porém, em nossas duas perguntas, as funções ditas superiores do homem, o prometer e a contensão civilizada dos impulsos agressivos, atendem ao que Descartes denominara res cogitans. Quando tais funções são entendidas como processos naturais, a res cogitans é rebaixada para aquém do corte epistemológico clássico, tornadas objetos do saber humano. A capacidade de prometer e o domínio civilizado das paixões agora são abordados pela ciência como fenômeno natural.

Se nossas duas perguntas implicam uma subversão do dualismo cartesiano, isso ocorre porque elas já não se encontram no horizonte epistêmico da ciência clássica. Ademais, elas implicam uma compreensão do homem como um organismo sujeito a mudanças profundas no tempo e, como tal, pressupõem um tempo do homem, aquele da criação de uma memória da vontade (Gedächtniss des Willens) ${ }^{2}$ e aquele da contenção da agressividade. Mas não há um tempo do homem sem que antes um tempo da vida tenha comparecido ao saber, o que igualmente foge ao horizonte do saber clássico.

Antes do século XIX, não se conhece um tempo do homem, nem a vida perfaz história. ${ }^{3}$ O século XVIII conhece um tempo da Terra. Cataclismos e catástrofes, afastamento dos mares e continentes comparecem quando a Terra deixa de ser imutável desde a criação. "Subitamente a Terra passa a ter história, idade, épocas" (JACOB, 1983, p. 138). Os

NIETZSCHE, 1998, p. 48; NIETZSCHE, 1988b, p. 292.

Segundo Foucault (1992, p. 165), na Idade Clássica, “o tempo jamais é concebido como princípio de desenvolvimento para os seres vivos na sua organização interna".

Revista de Filosofia, Curitiba, v. 17 n.20, p. 67-84, jan./jun. 2005. 
seres vivos mudam de lugar, pressionados pelo deslocamento das águas, mas eles mesmos não mudam (JACOB, 1983, p. 139). O século XVII dera à luz o conceito de espécie como permanência da estrutura visível através das gerações. Faz-se história natural pela taxinomia. Classifica-se pela nomeação. O nome discrimina a manutenção de um caráter e de uma ordem na estrutura visível dos animais e plantas que nascem idênticos a seus próprios pais (JACOB, 1983, p. 58). Obtêm-se, no mundo dos vivos, graças ao conceito de espécie, aquilo mesmo que a Idade Clássica procura por toda parte, a regularidade, a obediência às leis naturais (JACOB, 1983, p. 58). Leis que o são justamente por sua independência do tempo. Mas, no fim da Idade Clássica, supera-se o representacionismo da visibilidade como condição da classificação. Penetra-se na invisibilidade do corpo, concebendo-se o vivo como organização (JACOB, 1983, p. 90). Sua arquitetura oculta, seus órgãos e sistemas executam funções que se relacionam todas entre si, perfazendo uma unidade e uma totalidade em si mesma, dotada de uma lógica cuja dinâmica se denomina justamente vida (JACOB, 1983, p. 91-93). Antes do fim do século XVIII conheceramse os vivos, mas não a vida. ${ }^{4}$ No século XIX, a vida está sujeita ao tempo. Todos os vivos sofrem transformações orgânicas através das gerações. A espécie não é mais fixa. A vida, agora, perfaz uma história. O homem é um vivo entre outros.

É nessa abertura que nossas duas perguntas podem surgir. Freud pode especular sobre a "nova forma de vida alcançada com 0 porte ereto do homem" e as conseqüências orgânico-psiquícas, para a "primitiva existência animal". Conseqüências tais como "repressão orgânica", que teria criado a intolerância a odores genitais e excretórios, e a transferência da excitação sexual do olfato para a visão. ${ }^{5}$ Nietzsche, por sua vez, pode nos contar a fábula do homem que, invejando a felicidade do animal a pastar, pergunta-lhe: "'Por que você não me fala da sua

4 Vida é uma "força interna que luta contra o acaso e a destruição". Jacob (1993, p. 936) e Foucault (1992) estão de acordo quanto à relevância e à datação do conceito de vida. A vida não comparece antes de Kant e Vicq d'Azyr, enquanto se conhecem os vivos, mas não a vida. Apenas no final do século XVIII a vida tornar-se-á um conceito operatório como divisor de águas do saber. Foucault demarca o surgimento da vida entre os anos 1775 e 1795. François Jacob concorda quanto a esta datação, situa o surgimento do conceito na obra de Lamarck, La Flore Française, em 1778 e na Crítica da faculdade de julgar de Kant.

${ }^{5}$ FREUD, 1997, p. 53-4, Nota 1. Cf. também outra nota de FREUD (1997, p. 61-2). 
felicidade e se limita a me olhar? O animal - continua a narrativa gostaria de responder ao homem e lhe dizer: 'Isso é assim por eu esquecer exatamente o que gostaria de dizer' - mas o animal esquece também essa resposta e permanece mudo...". ${ }^{6}$ Nessa fábula, o que separa o homem do animal não é um ganho metafísico, mas a perda de um dote natural, a faculdade do esquecimento. O animal possui uma memória cumulativa da sensação, reconhece e lembra-se do caminho que o leva à água, do que é e do que não é alimento seu. No homem, a natureza produziu uma memória da vontade, um "ativo não-mais-querer-livrar-se, um "prosseguir-querendo o já querido" (NIETZSCHE, 1998, p. 48).

$\mathrm{Na}$ pena de nossos dois autores, a humanidade do homem mergulha num passado animal. $\mathrm{O}$ velho adágio Homo homini lupus não é mais uma metáfora da agressividade recíproca dos humanos ou a metafísica invertida de uma nova definição da natureza essencial do homem. Lupino é o passado e o presente humanos, numa densidade orgânica. $\mathrm{O}$ dito latino mergulha na história do corpo. O homem é lobo para o homem porque é irmão do lobo, na história da vida. Animal delirante, animal ridente, animal plangente, animal infeliz... assim Nietzsche aponta para o homem (apud SOUZA, 1999, p. 254). Mas a nota do zoon politikon que nos interessa acima de tudo aqui é a que afirma o homem como animal agressivo, violento, belicoso, cruel (ARISTÓTELES, 1985, p. 15). Uma nota que não distingue o bicho homem de entre as feras. Nota que lhe foi dada por Nietzsche e Freud.

Essa animalidade primitiva do homem longe está de deixar-se perder no passado. Para Freud (1997, p. 67; 81), "os homens não são criaturas gentis que desejam ser amadas e que, no máximo, podem defender-se quando atacadas; pelo contrário, são criaturas entre cujos dotes instintivos (Triebbegabungen), [está] uma poderosa quota de agressividade". O outro do homem é um objeto de satisfação da agressividade, para "explorar sua capacidade de trabalho sem compensação, utilizá-lo sexualmente sem o seu consentimento, apoderar-se de suas posses, humilhá-lo, causar-lhe sofrimento, torturá-lo e matá-lo." Essa inclinação humana para a ruindade, a agressividade, a destrutividade e a crueldade é inata, é "disposição instintiva original e auto-subsistente" (die Aggression sn eigung eine ursprüngliche, selbständige Triebanlage des Men schen).

6 NIETZSCHE, s/d, p. 94 (Da utilidade e inutilidade da história para a vida, § 1); NIETZSCHE, 1988a, p. 248.

Revista de Filosofia, Curitiba, v. 17 n.20, p. 67-84, jan./jun. 2005. 
Surpreendentemente, a introdução na psicanálise de um impulso independente de agressividade (Aggressionstrieb) ${ }^{7}$ deparou-se com resistências mais poderosas do que as oposições suscitadas nas sociedades ocidentais contra a introdução da sexualidade na infância. Em O mal-estar na civilização, somos informados por Freud (1997, p. 78) que não foi ele quem inaugurou na literatura psicanalítica o tema da agressividade e, quando de sua emergência, o pai da psicanálise confessa ter resistido à novidade. $O$ que o médico vienense tinha dificuldade em aceitar era a idéia de impulsos agressivos originalmente independentes em relação aos impulsos autopreservativos ${ }^{8}$. Mudou de opinião em Além do princípio do prazer (1920), causando resistências tais nos meios psicanalíticos que, dez anos depois, em O mal-estar na civilização (1930), perguntará a seus correligionários: "não posso mais entender como foi que pudemos ter desprezado a ubiqüidade da agressividade e da destrutividade não eróticas e falhado em conceder-lhe o devido lugar em nossa interpretação da vida" (FREUD, 1997, p. 78).

7 Afora as citações da Edição Standart Brasileira das Obras psicológicas completas de Freud e outras, verte-se a palavra alemã Trieb por impulso e não por instinto ou por pulsão, como se vem fazendo na literatura psicanalítica francesa e, por influência dela, em outras línguas, incluindo o português. Justifica-se com os seguintes argumentos de Paulo César de Souza (1999, p. 243-61): a) pulsion é, em francês e português um neologismo e b) a idéia de que Freud teria utilizado a palavra Instinkt, de origem latina, para referir-se a animais e Trieb, de origem germânica, para referir-se ao homem, não resiste a um rastreamento do uso dos termos na obra e introduz um preconceito teórico incompatível com a idéia freudiana de que, no plano dos impulsos vitais, há mais continuidade que descontinuidade entre o homem e o animal. Luiz Alberto Hanns corrobora os argumentos de Souza, mas opta pela palavra 'pulsão', nas novas Obras Psicológicas de Freud, cf. o texto de Hanns 'Os critérios de tradução adotados' (In: Freud, 2004, p. 15-60) e a nota a propósito de Trieb (In: Freud, 2004, p. 137-40). Hanns faz uso do neologismo porque o considera consagrado no campo psicanalítico brasileiro e porque a artificialidade da palavra oferece-lhe a possibilidade de dotar-lhe de notas motivadas a construir-lhe uma semântica tecnicamente circunscrita. Trieb é também um termo muito recorrente em Nietzsche, sendo vertido preferencialmente por impulso como também o faz Paulo César de Souza, atualmente, principal tradutor de Nietzsche no Brasil. (Cf. as notas de Souza In: NIETZSCHE, 1992, p. 216-20; NIETZSCHE, 1998, p. 154). Sobre esse assunto, Cf. tb. Hanns, 1996, p.338-54 e Assoun, 1989, p. 93-125.

8 Cf. a nota do Editor inglês James Strachey ao texto de O mal-estar na civilização (FREUD, 1974a, p. 193-6). 
Nietzsche, meio século antes, introduzira a idéia da agressividade humana em sua interpretação da civilização helênica pré-platônica. Civilização que erige em modelo de humanidade ainda não driblada pela moral enfraquecida das virtudes socráticas. O filólogo Nietzsche lembrará aos filósofos que os poetas trágicos celebram um mundo helênico exultante com o prazer da representação teatral da crueldade da guerra $^{9}$.

Quando Freud (1997, p. 81) torna operante em sua psicologia profunda o bellum omnium contra omnes, "o natural instinto agressivo do homem (der natürliche Aggressionstrieb der Menschen), a hostilidade de cada um contra todos e a de todos contra cada um", compreende-o como algo que se opõe ao programa da civilização..$^{10}$ É então que emerge a pergunta pelo que acontece para tornar inofensivo o desejo de agressão (Aggressionslust) do indivíduo (FREUD, 1997, p. 83). Só a contensão da agressividade tornaria possível a civilização ${ }^{11}$. Tarefa para a qual Freud encarrega um outro princípio, oposto à agressividade. A obra Além do princípio do prazer (1920) ${ }^{12}$ introduzira a idéia de uma dualidade de impulsos ${ }^{13}$ na qual a agressividade seria uma forma do impulso de morte e este estaria em oposição aos impulsos sexuais (Sexualtrieben), denominados 'Eros' por Freud, desde então. Eros procura manter juntas as partes da substância viva ${ }^{14}$, aproxima as células umas das outras no

9 NIETZSCHE, 1998, na Segunda Dissertação, o parágrafo 7. Cf. tb. NIETZSCHE, 1996a.

10 Por civilização (Kultur), Freud entende "a soma integral das realizações e regulamentos que distinguem nossas vidas das de nossos antepassados animais, e que servem a dois intuitos, a saber: a de proteger os homens contra a natureza e o de ajustar seus relacionamentos mútuos" (FREUD, 1997, p. 41-2). Nos textos circunscritos neste artigo, Freud utiliza Kultur em detrimento de Zivilisation. As duas palavras latinas ganharam, no uso alemão, sentidos análogos e antagônicos. Em O futuro de uma ilusão, Freud (1974a, p. 140) diz desprezar essa distinção alemã. Optou-se aqui por seguir a tradução de Kultur por Civilização, seguindo a Edição Standart Brasileira das Obras psicológicas completas de Freud.

${ }^{11}$ A agressividade é "o maior impedimento à civilização" (FREUD, 1997, p. 81).

12 Não é o caso discutir aqui a crítica contemporânea às teorias dos impulsos (ou pulsões) e instintos de Nietzsche e de Freud, mas é importante destacar a relevância filosófica desse debate. Cf. LOPARIC, 1999, p. 97-157

13 Para LAPLANCHE, J. e PONTALIS (2001, p. 394-6), trata-se de "manifestações pulsionais numa grande oposição fundamental" (Vocábulo Pulsão).

14 A "libido de nossos instintos sexuais coincidiria com o Eros dos poetas e dos filósofos, o qual mantém unidas todas as coisas vivas" (FREUD, 1976, p. 70). "Eros opera desde o princípio da vida e aparece como um 'instinto de vida', em oposição ao 'instinto de morte', criado pela animação da substância orgânica" (Freud, 1976, p. 82).

Revista de Filosofia, Curitiba, v. 17 n.20, p. 67-84, jan./jun. 2005. 
organismo multicelular, procura a perpetuação e a renovação da vida (FREUD, 1976, p. 65; 70; 82). De outro lado, lutando contra Eros ${ }^{15}$, os impulsos de morte conduzem o vivo à desagregação (FREUD, 1976, p. 65). Voltados contra o objeto, para sua destruição os impulsos de morte, fonte da agressividade humana, assumem a forma de impulsos destrutivos (Destruktionstrieben) (FREUD, 1976, p. 74). ${ }^{16}$ A civilização "constitui um processo a serviço de Eros, cujo propósito é combinar indivíduos humanos isolados, depois famílias e, depois ainda, raças, povos e nações numa única grande unidade, a unidade da humanidade". Propósito que só pode ser levado a cabo contra a agressividade (FREUD, 1997, p. 81).

É possível encontrar também em Nietzsche uma resposta para a pergunta de Freud. O que acontece para reprimir a agressividade é a violência da fundação originária do Estado. Em sua origem, o Estado tornou inofensivos os desejos de agressão daqueles a quem submeteu e escravizou. Surgido da guerra e da imposição do agressor sobre os vencidos, o Estado é um conquistador, uma organização guerreira, uma casta militar ${ }^{17}$, que impõe forma sobre matéria bruta, a população dispersa. A casta conquistadora e ordenadora produz uma unidade superior, numa diversidade de partes e funções, institui e executa a lei e o direito, aplica as penas, defende a neutralidade da justiça, assegura a ordem e a estabilidade social. ${ }^{18}$

A origem do Estado não extingue o bellum omnium contra omnes $^{19}$. No âmbito da casta guerreira que impôs o Estado, os instintos agressivos, mortais e guerreiros, continuam a manifestar-se livremente voltando-se para fora. Conforme o exemplo grego, os Estados vivem em guerra. ${ }^{20}$ Ao interno do Estado, a paz é possível graças a esses escoadou-

15 A vida é explicada pela ação concorrente, ou mutuamente oposta de Eros e do impulso de morte (FREUD, 1997, p. 77).

16 "Esse instinto agressivo é o derivado e o principal representante do instinto de morte, que descobrimos lado-a-lado de Eros e com este divide o domínio do mundo" (FREUD, 1997, p. 81). “Uma parte dos instintos de morte é desviada no sentido do mundo externo e vem à luz como instinto de agressividade e destrutividade" (Trieb zur Aggression und Destruktion) (FREUD, 1997, p. 77).

17 NIETZSCHE, 1996a; 2000, p. 75; 1996b, p. 169; 1998a, Segunda Dissertação, parágrafo 17.

18 NIETZSCHE, 1998, p. 64 e 75; 2000, p. 75.

19 NIETZSCHE, 1998, Segunda Dissertação, parágrafo 9.

20 "O grego considera como uma grave necessidade deixar escoar todo seu ódio" (NIETZSCHE, 1996a, p. 74). 
ros externos da agressividade e a sua canalização para as formas civilizadas da violência, tal como a rivalidade entre os partidos, entre os artesãos, entre os atletas, entre os artistas, entre os oradores, entre os sábios, entre os sofistas e entre os filósofos. Apenas graças a esse modo de lidar com a agressividade, a civilização grega tornou-se apogeu do humano (NIETZSCHE, 1996a, p. 53-4).

Para Freud, a agressividade é um impulso irresistível do animal homem para quem a civilização representa uma alteração inédita do modo de existência. Em Nietzsche, o Estado produzirá esse efeito. Seja com a civilização, seja com o Estado, uma restrição inédita na liberdade de movimento dos homens controlou a agressividade. Para Freud (1997, p. 83-4), a "civilização consegue dominar o perigoso desejo de agressão do indivíduo, enfraquecendo-o, desarmando-o", a "agressividade é introjetada, internalizada; ela é, na realidade, enviada de volta para o lugar de onde proveio". Voltada contra aquele que teria prazer em agredir e não mais contra os outros indivíduos a ele estranhos, a agressividade produz Schuld, culpa.

Nietzsche (1998, p. 73 e 75), por seu turno, é taxativo: "Todos os instintos (Alle Instinkte) que não se descarregam para fora voltam-se para dentro". Não é o caso dos fundadores do Estado porque sua agressividade pode continuar a escoar-se para fora pela guerra. Entre os gregos, a guerra é nobilitante. Não é aos residentes, escravos ou metecos que compete o dever e a honra de combater pelo Estado. É por isso que, quanto aos submetidos ao Estado, tudo se passa de modo bem diferente. Seus instintos de liberdade (Instinkte der Freiheit), "instintos do homem selvagem, livre e errante", o Estado fez com que "se voltassem para trás, contra o homem mesmo", fez com que se tornassem latentes à força, reprimido-os, fazendo-os recuar, encarcerando-os no íntimo, não deixando vazão para desafogarem-se a não ser contra si mesmos. O que resulta disso é má consciência moral (schlechtes Gewissen).

"Este homem que, por falta de inimigos e resistências exteriores, cerrado numa opressiva estreiteza e regularidade de costumes, impacientemente lacerou, perseguiu, corroeu, espicaçou, maltratou a si mesmo, esse animal que querem 'amansar', que se fere nas barras da própria jaula, este ser carente, consumido pela nostalgia do ermo, que a si mesmo teve de converter em aventura, câmara de tortura, insegura e perigosa mata - esse tolo, esse prisioneiro presa da ânsia e do desespero tornou-se o inventor da 'má consciência'”. (NIETZSCHE, 1998, p. 73).

Revista de Filosofia, Curitiba, v. 17 n.20, p. 67-84, jan./jun. 2005. 
Má consciência moral é um sentimento de desgraça e malestar, uma espécie de verme roedor um sofrimento do homem consigo mesmo, do homem oprimido pelo Estado (NIETZSCHE, 1998, p. 70;73). Uma "vontade de maltratar-se", uma "oculta violentação de si mesmo", uma "crueldade de artista... em se impor a ferro e fogo uma vontade, uma crítica, uma contradição, um não". Só nasce no âmbito da sociedade (Gesellschaft), que é construção do Estado. Não viceja entre os organizadores e artistas da violência, os criadores do Estado, mas "sem eles ela não teria nascido" (NIETZSCHE, 1998, p. 75-6).

Culpa para Freud, má consciência para Nietzsche, são resultados da restrição da agressividade natural do homem. Um voltar-se para dentro da agressividade que não pode mais ser externada. Neste ponto, não podemos deixar de atentar para o fato de que Nietzsche, ao falar de má consciência moral e Freud ao falar em culpa, utilizaram-se de palavras do vocabulário do homem comum, guarnecidas de uma sedimentação semântica cujo extrato derradeiro, o mais recente, devemo-lo ao cristianismo. Pela oração do pai-nosso, todo o mundo cristão pede perdão de dívidas ou culpas como sinônimo de uma ofensa a Deus e aos irmãos.

Na tradição tomista do cristianismo, há uma instância espiritual, a consciência moral que aprova ou reprova o ato moral, conforme seja bom ou mau. Os sentimentos morais de "alegria pelo dever cumprido, ou de tristeza e insatisfação pelo dever violado" decorrem da apreciação da consciência moral que recompensa ou castiga. Sentimento de culpa, vergonha, remorso e arrependimento são decorrentes das censuras da consciência moral, cujo fundamento é o senso moral, "o sentimento imediato e absoluto da lei reguladora do conhecimento e da ação práticos" (JOLVET, 1966, p. 13). Na tradição tomista, o senso moral define-se essencialmente pelo princípio de que "é preciso fazer o bem e evitar 0 mal", possuindo a infalibilidade da natureza da inteligência humana. ${ }^{21}$ À consciência do ato mau corresponde o remorso ou morsus conscientiae, a mordida da consciência, mas a consciência de culpa pode ligar-se também à intenção ou ao desejo do mal ou da má ação. Pode-se pecar por atos ou intenções.

Quando Freud fala de culpa e Nietzsche, de má consciência, como resultantes da interiorização da agressividade, iniciam por afastar as conota-

${ }^{21}$ Tomás de Aquino, De Veritate, q. XVI, art. 1 e 3, apud JOLIVET, 1966, p. 99 e 182. 
ções procedentes do cristianismo. Freud (1997, p. 84) denega "a existência de uma capacidade original, por assim dizer, natural de distinguir o bom do mau". Nietzsche (1998, p. 71) retoma a posição de Spinoza, que reduziu bem e mal ao reino das coisas humanas e, conseqüentemente, o conteúdo teológico do morsus concientiae a "uma tristeza acompanhada da idéia de uma coisa passada, cujo desfecho traiu a expectativa".22 Para Nietzsche como para Freud, os sentimentos morais não são produzidos por nenhuma instância moral de bem e mal, fixada pelo criador na natureza humana sob a forma de senso ou consciência moral. Essa denegação da metafísica, entretanto, é o primeiro ato no trabalho de escavação que prosseguirá em cada um dos dois autores por vias e instrumentos próprios.

Nietzsche (1998, p. 59) propõe que a palavra Schuld denotava apenas 'dívida' antes que um revestimento nosológico moral lhe agregasse o sentido de 'culpa'. A dívida apareceu na relação comercial, a "mais antiga e primordial relação pessoal". "Não foi ainda encontrado um grau de civilização tão baixo que não exibisse algo dessa relação". Entre comprador e vendedor, devedor e credor fazem-se promessas: aparece o contrato. Necessita-se que o devedor recorde-se de sua dívida. "É preciso construir uma memória naquele que promete" (NIETZSCHE, 1998, p. 53). Aí está o problema de Nietzsche: como "criar um animal que pode 'fazer promessas'?'. Como produzir uma memória no bichohomem, como "gravar algo indelével nessa inteligência voltada para 0 instante, meio obtusa, meio leviana, nessa encarnação do esquecimento?'. Esse problema foi resolvido pela mnemotécnica da dor. "Grava-se algo a fogo, para que fique na memória: apenas o que não cessa de causa dor fica na memória” (NIETZSCHE, 1998, p. 50). “O devedor para infundir confiança em sua promessa de restituição empenha ao credor [...] algo que ainda 'possua' [...], como seu corpo, sua mulher, sua liberdade ou mesmo sua vida" (NIETZSCHE, 1998, p. 53-4). Isso confere ao credor o direito de "cortar ao corpo do devedor o que fosse proporcional à dívida". Essa equivalência substitui o dano do credor por uma reparação, a satisfação de fazer sofrer, o prazer de ultrajar o corpo do devedor (NIETZSCHE, 1998, p. 54). No limite, dívida resgata-se com dor, porque a dor do devedor é prazer para o credor (NIETZSCHE, 1998, p. 53; 59). A continuidade da vontade se faz pela continuidade da dor. ${ }^{23}$

\footnotetext{
${ }^{22}$ A referência de Nietzsche (1998, p. 71) para sua citação de Spinoza é Ethica III propos. XVIII schol. I.II.

${ }^{23}$ Cf. o capítulo 'Culpa', 'má consciência' \& companhia. (AZEREDO, 2000, p. 58-137).
}

Revista de Filosofia, Curitiba, v. 17 n.20, p. 67-84, jan./jun. 2005. 
Para Nietzsche, portanto, o sentimento de dívida tem uma origem anterior à origem da má consciência moral. A origem do sentimento de dívida não se distingue da origem da consciência perspectiva da dívida (Bewustsein der Schuld), pois conhecimento da dívida e lembrança da dívida são o mesmo, igualmente originados pela permanência temporal do medo da dor em conseqüência do não cumprimento da promessa. Para Nietzsche, então, a relação comercial produziu a cognição. "Estabelecer preços, medir valores, imaginar equivalências, trocar - isso ocupou de tal maneira o mais antigo pensamento do homem, que num certo sentido constituiu o pensamento". Homem, lembra Nietzsche em mais um argumento de ordem filológica, que se designa em alemão por Mensch e manas em sânscrito, é exatamente o animal que realiza a tarefa de medir ou mensurar, em alemão messen ou abmessen..$^{24}$

Por outro lado, poder prometer é um "poder responder por si", um "poder também dizer sim a si mesmo" (NIETZSCHE, 1998, p. 50). O sentimento de dívida é lembrança da obrigação pessoal (NIETZSCHE, 1998, p. 59). Assim, a consciência moral, na origem, é sentimento de dívida, porque a menemotécnica da dor pode "reforçar na consciência moral (Gewissen) a restituição como dever e obrigação" (NIETZSCHE, 1998, p. 53). A própria eticidade dos costumes não é outra coisa que a produção da memória de um conjunto de dívidas contraídas pelo indivíduo para com a comunidade. A religiosidade da casta nobre, fundadora do Estado, ao deificar seus antepassados, também associa aos sucessos do Estado uma dívida para com os deuses fundadores da estirpe (NIETZSCHE, 1998, p. 76-8).

Há um momento, entretanto, a partir do qual a consciência perceptiva de ter dívidas (Bewusstsein von Schulden gegen) identifica-se com a má consciência moral (schlechte Gewissen) (NIETZSCHE, 1998, p. 52). É o momento em que os portadores da má consciência adaptando-se ao culto dos senhores, assimilando seus deuses, dão à dívida (Schuld) um conteúdo moral (NIETZSCHE, 1998, p. 78-9). A dívida dos senhores para com seus deuses, toma-se culpa na sua apropriação por parte dos escravos. ${ }^{25}$ Neles, a noção de culpa volta-se para trás e, entrelaçada à má consciência, lança

${ }^{24}$ De acordo com o tradutor Paulo César de Souza (in: NIETZSCHE, 1998, p.156, nota 10), em sânscrito manas significa 'consciência'.

${ }^{25}$ Que a má consciência e a moralização da noção de dívida tenham lugar naquele que está "aprisionado no Estado" e não na casta que é o Estado (NIETZSCHE, 1998, p. 81) é da maior importância aqui por ser fundamental atentar pelas perguntas "Quem?", "Qual a sua posição entre os que se relacionam?' quando se trata de compreender o pensamento de Nietzsche. Sobre isso, cf. Deleuze (s/d, p. 82).

Revista de Filosofia, Curitiba, v. 17 n.20, p. 67-84, jan./jun. 2005. 
raízes, cresce e corrói o interior daquele que se sente culpado. A impossibilidade de penitência gera a idéia de um castigo eterno. A idéia amplia-se, atinge o gênero humano: todo ele é amaldiçoado, como na narrativa do pecado de Adão. A própria natureza é demonizada. O mundo sensível e o corpo tornam-se fonte de pecado. A má consciência, como violência interiorizada e entrelaçada à noção moral de culpa, toma então a conhecida forma da negação, nojo e vergonha da vida, do corpo, da sexualidade e dos instintos (NIETZSCHE, 1998, p. 79-80; 56-7). A violência contra si, a má consciência, produz os ideais negativos: a abnegação, o sacrifício de si, o desinteresse, o não egoísmo (NIETZSCHE, 1998, p. 76).

A via de Freud será outra. Depois da remoção semântica da metafísica da consciência moral, Freud avança sua escavação no plano do desenvolvimento orgânico-psíquico humano. A consciência moral é uma possibilidade no desenvolvimento da criança. O medo infantil da perda do amor dos pais é, ao mesmo tempo, medo da exposição ao perigo da agressão punitiva da autoridade parental. É ainda em função desse medo que a criança renuncia à satisfação dos instintos. Renúncia que dá lugar a uma agressividade contra a autoridade. Mas a criança é obrigada a renunciar também à satisfação dessa agressividade vingativa. A saída encontrada, segundo a hipótese freudiana, é a identificação da criança com a autoridade inatacável, que é incorporada produzindo uma alteração psíquica na mente infantil, uma "gradação" ou "diferenciação" dentro do eu denominada Über-Ich, o supereu, desde a obra de 1923, O eu e o isso. O eu é a instância mental (seelische Instanz) a que se liga a consciência perceptiva, que é a superfície do aparelho mental (das Bewu sstsein ist die Oberfläche des seelischen Apparrate) atingida por percepções oriundas do mundo externo e as do interior, a que denominamos sentimentos (FREUD, 1975, p. 286; 288). O eu "controla as abordagens à motilidade" e "vai dormir à noite" (FREUD, 1975, p. 286). O supereu é um agente do eu, capaz de agredir o eu com a agressividade que a criança tinha contra a autoridade (FREUD, 1997, p. 83; 90-1). Essa tensão entre o supereu agressivo e o eu agredido dá origem ao sentimento de culpa (Schuldgefühls).

A agressividade contra a autoridade inatacável é deslocada para dentro introjetada, internalizada e assumida pelo supereu, dando origem à consciência moral, que é uma função do supereu (FREUD, 1997, p. 83; 90-91; 102). Desde O eu e o isso, Freud associara a ação do supereu aos impulsos de agressividade provenientes do instinto de morte, mas em $\mathrm{O}$

Revista de Filosofia, Curitiba, v. 17 n.20, p. 67-84, jan./jun. 2005. 
mal-estar na civilização, torna-se inequívoca a distinção entre a origem do supereu, como identificação, da origem da consciência moral, como agressividade internalizada. A renúncia cria dinamicamente a consciência moral, de tal forma que cada agressão externa declinada é vertida em agressividade da consciência moral contra o eu, aumentando o rigor da consciência e o peso do sentimento de culpa (FREUD, 1997, p. 83; 90-1). Daí a identidade entre sentimento de culpa, severidade do supereu e severidade da consciência moral (FREUD, 1997, p. 99).

Freud (1997, p. 88; 100), entretanto, postula a existência de um sentimento de culpa anterior à formação do supereu que é idêntico ao medo da autoridade externa e é mais antigo que a consciência moral. Numa primeira fase do desenvolvimento infantil, o medo da perda do amor dos pais gera uma "ansiedade social" (soziale Angst), período em que é impróprio falar em consciência moral. Para Freud (19974, p. 85) é possível que determinados indivíduos nunca ultrapassem essa fase. É 0 caso de adultos desprovidos de consciência moral que só evitam fazer algo condenável pela possibilidade ou medo de serem descobertos. Só há propriamente consciência moral, quando a autoridade parental e social é internalizada psiquicamente pelo estabelecimento de um supereu, situação em que uma pessoa age moralmente e não por medo de ser descoberta, mas segundo ditames do supereu do qual a intenção não pode ser escondida. Esclarecer-se-á, assim, psicologicamente, porque há sentimentos de culpa aos quais não correspondem atos maus.

Além da explicação ontogenética da origem da consciência moral, Freud elaborou também uma explicação filogenética. Em Totem e tabu, obra de 1913, Freud expressara a hipótese de uma agressividade da horda primitiva de irmãos contra o poder do pai que resultou na morte deste. Em O mal-estar na civilização, Freud (1997, p. 93-4) propõe-se o problema de que a morte do pai primevo teria escoado a agressividade, não podendo mais dar origem à consciência moral, já que não há mais agressividade para ser internalizada. A resposta de Freud é que, da ambivalência de sentimento de amor e ódio pelo pai primevo, após a satisfação da agressividade pelo assassinato, ressurge o amor e comparece 0 sentimento de culpa pelo ato praticado. A identificação com o pai morto cria o supereu com o poder de punição pelo assassinato, a culpa. Daí a conclusão freudiana de que o tabu seja a proibição de matar e comer o animal totêmico, que é o representante psíquico do pai. Seja pela via ontogenética, seja pela via filogenética, a civilização consegue dominar e

Revista de Filosofia, Curitiba, v. 17 n.20, p. 67-84, jan./jun. 2005. 
enfraquecer a agressividade do indivíduo "estabelecendo no seu interior um agente para cuidar dele", o supereu (FREUD, 1997, p. 84).

\section{Conclusão}

Pisando sobre um mesmo solo epistêmico produzido historicamente pelo nascimento do conceito de vida, pela distinção ôntica entre o orgânico e o inorgânico e pela introdução do tempo no âmbito da vida, Nietzsche e Freud acabaram por dar à luz uma compreensão muito próxima do significado da repressão dos impulsos agressivos do homem e sua relação com a culpa. ${ }^{26}$ A confluência das concepções de Freud e Nietzsche quanto à formação da consciência moral conduz a uma referência de concordância explícita da parte de Freud (1969, p. 253) sobre a posição psicológica de Nietzsche quanto ao sentimento de culpa dos criminosos. Para ambos os autores, não é a punição do crime que produz esse sentimento, antes é a culpa que produz o crime. Para Freud (1975, p. 319), em determinados criminosos "é possível detectar um sentimento de culpa muito poderoso, que existia antes do crime, e, portanto, não é seu resultado, mas sim o seu motivo". Segundo Nietzsche (1998, p. 70), "entre prisioneiros e criminosos o autêntico remorso é algo raro ao extremo, as penitenciárias e casas de correção não são o viveiro onde se produz essa espécie de verme roedor" ${ }^{27}$ Sabemos as conseqüências pragmáticas de ordem pedagógica, ética, jurídica e política de considerável relevância resultantes desse ponto de acordo entre os dois pensadores. Mas são as diferenças presentes nesta zona de tangência que mais incitam à reflexão e exigem maior profundidade de mergulho em suas obras.

${ }^{26}$ A proximidade temática entre Freud e Nietzsche a propósito da culpa, foi tratada por Assoun (1989, p. 237-42) e por Giacoia Junior (2001, p. 101-52), em seu ensaio Esquecimento, memória e repetição. Este, percorrendo os conceitos indicados no seu título, chega a algumas das mesmas conclusões apontadas neste artigo. $\mathrm{O}$ que se faz aqui, entretanto, não é uma compilação temática que excursiona a obra completa dos dois autores para pontualizar o aparecimento dos temas e conceitos, como faz Assoun, mas seguir o fio condutor do conceito de agressividade, como destacada origem ou fonte da culpa, que não é a via de Giacoia Junior.

27 Sobre a questão do sentimento de culpa nos criminosos, em Nietzsche e em Freud, cf. Assoun (1989, p. $76-7$ e 245).

Revista de Filosofia, Curitiba, v. 17 n.20, p. 67-84, jan./jun. 2005. 
Em Nietzsche, a má consciência, seu entrelaçamento com a noção moralizada de dívida (Schuld), a culpa, e seu afundamento na consciência moral (Gewissen) é resultado de uma pressão extema contra a agressividade do indivíduo. Agressividade que é obrigada a interiorizar-se. A consciência moral não é uma instância da mente. A eticidade dos costumes não é outra coisa que a memória das dívidas do indivíduo para com os benefícios da comunidade. Em conseqüência dessas concepções, o sentimento de culpa, como má consciência ou remorso, é uma doença que se perpetua no plano da cultura, sendo inteiramente possível e, aliás, sumamente desejável que algum homem possa nascer, crescer e lançar-se para além da configuração do humano que conhecemos, sem má consciência ou culpa. Uma configuração psicológica do indivíduo e da cultura completamente diversa seria possível. Daí a estima de Nietzsche (1998, p. 83) pelos gregos trágicos. Antes de Sócrates, na esfera do Estado, não há má consciência. Os deuses gregos deviam "justificar o homem também na ruindade; serviam como causas do mal...". Deles era o papel de manter afastada a má consciência, já que eles "naquele tempo não tomavam a si o castigo, e sim, o que é mais nobre, a culpa...". ${ }^{28}$

Freud (1997, p. 88) refere-se a um estágio pré-histórico no qual o homem não teria sentimento de culpa. "É digno de nota - diz ele - o comportamento tão diferente do homem primitivo. Se ele se defronta com um infortúnio, não atribui a culpa a si mesmo, mas a seu fetiche, que evidentemente não cumpriu o dever, e dá-lhe uma surra, em vez de se punir a si mesmo". Freud reconhece a possibilidade de o indivíduo não desenvolver a identificação com a figura parental e, conseqüentemente, não constituir a função moral do supereu. Esse indivíduo viveria sem culpa. Porém, para Freud, sem culpa não há consciência moral, nem eticidade autêntica no indivíduo, mas apenas medo de punição. Se é verdade que a saúde psíquica depende de um supereu menos rigoroso e cruel do que o das histéricas, também o é que o futuro da civilização não dispensa uma culpa sob medida. Para Nietzsche, a eticidade superior é justamente consciência ética como lembrança da dívida e palavra dada a honrar: não culpa.

Por outro lado, a hipótese freudiana de um sentimento inconsciente de culpa por trás de toda doença psíquica, idéia aqui não desenvolvi-

28 Em Ecce Homo, depois de notas sobre a cortesia do próprio autor da autobiografia na retribuição às ofensas recebidas na vida, Nietzsche (1995, p. 30) apresenta esse traço da religião grega como princípio do seu próprio agir: "Um deus que viesse à Terra não poderia 'fazer' senão injustiça - tomar a si não a pena, mas a 'culpa', é que seria divino". 
da, coloca-nos novamente na estaca zero. É como se ainda não tivéssemos aprendido nada sobre o tema da culpa. Mas podemos nos dar por satisfeitos se tivermos dado um passo na história dos saberes e chegado à conclusão de que o problema da culpa é um objeto vivo do saber de que somos contemporâneos, as assim chamadas ciências do homem.

\section{Referências}

ASSOUN, Paul-Laurent. Freud e Nietzsche: semelhanças e dessemelhanças. São Paulo, SP: Brasiliense, 1989.

AZEREDO, Vânia Dutra de. Nietzsche e a dissolução da moral. São Paulo,SP: Discurso, 2000.

DELEUZE, Gilles. Nietzsche e a filosofia. Tradução de Edmundo Fernandes Dias e Ruth Joffily Dias. Rio de Janeiro: Rio, 1976.

FREUD, Sigmund. Bildende Kunst und Literatur. In: Studienausgabe. Frankfurt sobre o Meno: S. Fischer, 1972. v. 10.

. Fragen der Gesellschaft Ursprünge der Religion. In: Studienausgabe. Frankfurt sobre o Meno: S. Fischer, 1974a. v. 9.

. Por que a guerra? In: OBRAS psicológicas completas. Rio de Janeiro, RJ: Imago, 1974b. (Edição Standart Brasileira, v. 12).

. Psycohologie des Unbewussten. In: Studienausgabe. Frankfurt sobre o Meno: S. Fischer, 1975. v. 3.

. Além do princípio do prazer. In: OBRAS psicológicas completas. Rio de Janeiro, RJ: Imago, 1976. (Edição Standart, Brasileira, v. 13).

. O mal-estar na civilização. Rio de Janeiro, RJ: Imago, 1997.

. Escritos sobre a psicologia do inconsciente. In: Obras psicológicas de Sigmund Freud. Rio de Janeiro, RJ: Imago, 2004. v. 1.

FOUCAULT, Michel. As palavras e as coisas. São Paulo, SP: Martins Fontes, 1992.

GIACOIA JUNIOR, Oswaldo. Nietzsche como psicólogo. 2. imp. São Leopoldo: Unisinos, 2001.

HANNS, Luiz. Dicionário comentado do alemão de Freud. Rio de Janeiro: Imago, 1996.

Revista de Filosofia, Curitiba, v. 17 n.20, p. 67-84, jan./jun. 2005. 
JACOB, François. A lógica da vida: uma histónia da hereditariedade. Rio de Janeiro, RJ: Graal, 1983.

JOLVET, Régis. Tratado de filosofia: Moral. Tradução de Gerardo Dantas Barreto. Rio de Janeiro, RJ: Agir, 1966. v. 4.

LAPLANCHE, J.; PONTALIS, J.-B. Vocabulário da psicanálise. São Paulo, SP: Martins Fontes, 2001.

LOPARIC, Zeljko. O conceito de 'Trieb' na psicanálise e na filosofia. In: MACHADO, Jorge A. T. (org.). Filosofia e psicanálise: um diálogo. Porto Alegre: Edipucrs, 1999. p. 97-157.

NIETZSCHE, F. Unzeitgemässe Betrachtungen. Zweites Stück. Vom Nutzen und Nachtheil der Historie für das Leben. In: Sämtliche Werke. Berlim: Walter de Gruyter, 1988a. v. 2.

. Zur Genealogie der Moral. In: Sämtliche Werke. Berlim: Walter de Gruyter, 1988b. v. 5.

Além do bem e do mal: prelúdio a uma filosofia do futuro. Tradução de Paulo César de Souza. São Paulo, SP: Companhia das Letras, 1992.

. 2. ed. São Paulo, SP: Companhia das Letras, 1996b.

Ecce Homo: como alguém se torna o que é. Tradução de Paulo César de Souza. São Paulo, SP: Companhia das Leras, 1995.

. Cinco prefácios para cinco livros não escritos. Tradução de Pedro Süssekind. Rio de Janeiro, RJ: Sette Letras, 1996a.

. Genealogia da moral: uma polêmica. Tradução de Paulo César Lima de Souza. São Paulo, SP: Companhia das Letras, 1998.

Humano, demasiado humano: um livro para espíritos livres. Tradução de Paulo Cezar de Souza. São Paulo, SP: Companhia das Letras, 2000.

. Da utilidade e inutilidade da história para a vida. In:

Considerações intempestivas. Tradução de Lemos de Azevedo. Lişōo: Presença, 1976.

SOUZA, Paulo César de. As palavras de Freud: o vocabulário freudiano e suas versões. São Paulo, SP: Ática, 1999.

Recebido em: Received in: 22/02/2005 Aprovado em: Approved in: 05/03/2005 